\title{
KEPRIBADIAN MANUSIA SUNDA DALAM KUMPULAN CERITA PENDEK TAHUN 1950-AN SAMPAI TAHUN 2000-AN
}

\author{
Nuraliawati \\ SMPN 4 Batujajar \\ Pos-el: nuraliawatia@yahoo.com
}

\begin{abstract}
Abstrak
Penelitian ini bertujuan untuk mendeskripsikan kepribadian manusia Sunda yang ada dalam Cerpen tahun 1950-an sampai tahun 2000-an, dengan menggunakan pendekatan psiko-logi sastra yang bertitik tolak dari asumsi bahwa karya sastra itu sering membahas kejadian dan tingkah laku manusia yang bermacam-macam. Metode yang digunakan dalam penelitian ini adalah metode deskriptif. Sedangkan tehnik yang digunakan meliputi telaah pustaka, observasi, dan analisis wacana. Berdasarkan hasil penelitian, kepribadian manusia Sunda yang ada dalam cerpen tahun 1950-an sampai tahun 2000-an meliputi beberapa sifat yang menjadi kepribadiannya. Diantaranya penampilan dan perkataan yang baik, teguh pendirian, teguh terhadap aturan agama, ramah, sabar, ikhlas, jujur, tidak pernah putus asa, tegas, mandiri, tawakal, bijaksana, mencintai tanah leluhurnya, mempunyai rasa kemanusiaan, cepat marah, sombong, dan suka menipu.
\end{abstract}

Kata kunci: kepribadian, manusia Sunda, cerita pendek

\section{THE PERSONALITY OF SUNDANESE PEOPLE IN A COMPILATION OF SHORT STORIES FROM 1950s TO 2000s}

\begin{abstract}
This research aimed at describing the personality of Sundanese people in short stories from 1950s to 2000s by means a literary psychology approach. It departs from an assumption that literary works often reveal a range of incidents and people's behaviors. The method used in this research is a descriptive method by employing techniques such as observation, document analysis and discourse analysis. Results indicate that the personality of Sundanese people depicted in short stories from 1950s to 2000s includes a number of characters, among others good words and nice appearance, strong will, adherence to religious teachings, being courteous, patient, sincere, honest, resilient, firm, self-reliant, wise, humanist, succumb to God's will and love one's homeland. Other characters include ill-tempered, arrogant and deceitful.
\end{abstract}

Keywords: personality, Sundanese people, short stories

\section{PENDAHULUAN}

Kegiatan penelitian untuk menghimpun beberapa orang Sunda yang dianggap mampu untuk memegang jabatan kenegaraan di tingkat pusat, pernah diadakan di tatar Sunda taun 2009. Dari beberapa orang Sunda yang disusun dalam angket, masarakat Jawa Barat diharapkan dapat memilih beberapa orang diantara mereka untuk dirangking dan hasilnya akan diajukan menjadi calon dalam 
pemilihan umum presiden dan wakil presiden. Tujuannya agar beberapa orang Sunda yang dipilih oleh masyarakat Jawa Barat dijadikan calon untuk memegang jabatan menteri atau jabatan-jabatan kenegaraan lainnya. Terlepas dari pro dan kontra masyarakat Jawa Barat (Sunda), kegiatan itu diadakan berdasar pada stereotif bahwa orang Sunda itu mempunyai sifat selalu mengalah seandainya diminta untuk menjadi pemimpin, padahal dirinya mampu, baik itu secara intelektual maupun secara politik.

Stereotif manusia Sunda tidak selamanya negatif sebagaimana di uraikan di atas, banyak sifat manusia sunda yang positif seperti jujur, teguh pendirian dan mempunyai keyakinan yang tebal terhadap satu hal. Sebagaimana yang di-gambarkan oleh (Rosidi, 2009:1-2) Bahwa ciri-ciri dan karakter khas manusia sunda itu berdasar pada dua tokoh sastra dan tokoh sejarah. Beberapa tokoh sastra (lama dan baru) yang dijadikan sampel, diantaranya Sangkuriang, Si Kabayan, Mundinglaya Di Kusumah. Purba Sari Ayu Wangi, Raden Yogaswara, Dewi Pramanik (Ratna Suminar) dan Karnadi. Sedangkan tokoh sejarah meliputi Dipati Ukur, Ki Tapa, Pangeran Kornel, Haji Hasan Mustapa dan Dewi sartika.

Ciri-ciri dan karakter khas beberapa tokoh yang disebutkan di atas menu-rut Rosidi belum bisa menggambarkan ciri dan karakter khas manusia Sunda secara umum. Nilai-nilai dan sifat-sifat tertentu yang dimiliki tokoh-tokoh tersebut bisa jadi ada pada diri manusia Sunda secara umum, tapi untuk menyimpulkan bahwa ciri dan karakter khas manusia Sunda seperti yang terlihat pada diri tokoh-tokoh tersebut, memerlukan pemikiran dan representasi yang lebih luas.

Walaupun penelitian tentang manusia sunda pernah dilaksanakan, tapi gambaran tentang manusia Sunda belum ditelusuri secara utuh. Selain Rosidi, penelitian terhadap manusia Sunda pernah dijelaskan dalam beberapa makalah di seminar- seminar dan penelitian yang dilaksanakan oleh Rusyana dan teman-teman. Mengenai pandangan hidup orang Sunda dari tradisi lisan, sastra Sunda dan kehidupan seharihari (tahun 1987-1989), walau tidak secara khusus menggambarkan kepribadian manusia Sunda, tapi bisa dijadikan bahan yang akan mengantarkan pemahaman terhadap bagaimana ciri dan karakter khas kepribadian manusia Sunda.

Ciri dan karakter manusia yang memperlihatkan kepribadian manusia Sunda bisa diteliti dari potensi dasar yang dimiliki oleh manusia itu sendiri. Karena manusia lahir ke dunia dibarengi oleh bermacammacam kemampuan atau potensi yang bisa dijadikan kekuatan untuk menjalani kehidupannya.

Potensi yang dimiliki manusia meliputi jasmani, akal dan roh. Setiap potensi mempunyai posisi dan kekuatan yang sama penting, diibaratkan satu bentuk bangunan yang mempunyai tiga sisi yang sama panjangnya. Kesempurnaan dan perkembangan keribadian manusia sunda akan banyak tergantung pada kesesuaian tiga potensi tadi. Dengan potensi dasar itulah manusia dapat menghadapi serta menyelesaikan masalah yang dihadapinya.

Masalah yang sifatnya empiris, dihadapi manusia dengan potensi jasmani, sedangkan masalah yang sifatnya logis dihadapi dengan potensi akal. Potensi roh digunakan manakala manusia itu berhadapan dengan persoalan hidup yang tidak empiris dan tidak logis.

Reaksi manusia terhadap potensi dasar yang ada pada diri manusia itu sendiri menghasilkan bermacam-macam kegiatan. Salah satunya adalah kegiatan menggunakan bahasa. Kegiatan kreatif manusia dalam menggunakan bahasa diantaranya bisa diekspresikan melalui kegiatan sastra. Hal ini sesuai dengan pemikiran Rusyana (1987:311), bahwa sastra itu ada dalam dunia fiksi, yang merupakan hasil kreatif manusia, hasil penelitian, tanggapan, fantasi, pikiran, 
perasaaan dan keinginan yang berbaur satu sama lain, lalu diwujudkan menggunakan bahasa.

Sastra menjelma karena adanya dorongan-dorongan dari rasa dan keinginan manusia untuk menjelaskan isi hati, pengalaman, dan keinginan untuk saling mempengaruhi satu sama lain.

Perkembangan karya sastra tidak lepas dari perkembangan ilmu pengetahuan yang ada di luar dunya sastra itu sendiri, termasuk hubungannya dengan konsep kehidupan. Sehubungan dengan itu, muncul sebuah konsep yang menjelaskan adanya hubungan yang sangat erat antara fenomena sastra dan cermin kehidupan.

Manfaat dari penelitian ini secara keilmuan adalah 1) memperkuat atau menambah wawasan pengetahuan tentang sastra Sunda, terutama dalam cakupan struktural dan psikologi sastra. 2) memperkuat atau menambah wawasan pengetahuan tentang aplikasi sastra menggunakan pendekatan psikologi sastra yang dihubungkan dengan konsep psikoanalisis.

Secarapraktis, penelitianinimemberikan manfaat untuk: 1) menentukan gambaran kepribadian manusia Sunda dari hasil-hasil karya orang Sunda. Hal ini dapat ditemukan dari bermacam-macam karya sastra, biografi, pemikiran-pemikirannya dan dari kehidupan sehari-harinya, 2) dijadikan dokumentasi tentang perkembangan manusia Sunda dari masa ke masa, 3) dijadikan alternatif bahan pelajaran di sekolah atau di masyarakat.

\section{METODE}

Metode yang digunakan dalam penelitian ini adalah metode deskriptif, yang bertujuan untuk memberikan gambaran kepribadian dalam cakupan struktur organisasi, dinamika dan perkembangannya dalam satu deskripsi situasi. Tehnik penelitian dalam penelitian ini mencakup telaah pustaka, observasi dan analisis wacana. Tehnik telaah pustaka dan observasi digunakan untuk mencari dan menemukan bahan pustaka serta data yang ada hubungannya dengan masalah yang diteliti. Dengan menggunakan tehnik analisis wacana, bahan yang sudah dikumpulkan, lalu dianalisis serta dipahami isinya sampai ditemukan korelasinya atau hubungannya dengan masalah yang diteliti.

\section{HASIL DAN PEMBAHASAN}

Kumpulan cerpen dalam penelitian ini adalah karangan fiksi dalam bentuk prosa yang pendek, dan mempunyai sifat naratif. Cerpen tersebut diciptakan dan diterbitkan dalam bentuk buku kumpulan cerpen tahun 1950-an sampai tahun 2000-an.

Cerita pendek yang sering disingkat cerpen adalah suatu bentuk prosa naratif dan fiktif yang cenderung padat dan langsung pada tujuan. Karena padatnya, cerpen sukses mengandalkan tehnik-tehnik sastra seperti tokoh, plot, tema, bahasa dan insight secara lebih luas dibanding fiksi lainnya yang lebih panjang.

Dalam sastra Sunda cerpen merupakan istilah terjemahan dari bahasa Inggris short story, karena cerpen berasal dari sastra Eropa. Dilihat dari bentuknya, cerpen merupakan karangan prosa yang pendek. Ukuran pendek, belum bisa menggambarkan satu cerita pendek, sebab dongeng juga merupakan prosa naratif yang pendek. Oleh sebab itu, perlu diperhatikan karakteristik carpon dari sifat-sifat naratifnya. Tapi jika memperhatikan karya-karya dalam sastra Sunda, akan terlihat bentuk cerpen yang pendek tersebut. Untuk membaca satu buah cerpen, hanya menghabiskan waktu antara 10 sampai 30 menit. Jumlah kata yang digunakan dalam cerpen umumnya tidak lebih dari 5000 kata. Tebalnya pun lebih kurang antara 3 sampai 6 halaman (Nurgiyantoro, 2009:10).

Cerita pendek, dalam sastra Sunda dimulai ada pada abad ke-20, yang lahir melalui media cetak majalah dan Koran. Beberapa media cetak yang lahir dalam rangka upaya menyalurkan karangan orang Sunda adalah Papaes Nonoman (1951), 
Padjadjaran (1918, tahun 1929 berubah menjadi Parahyangan), Volsalmanak Sunda (1919), Pustaka Sunda (1923) dan panghegar
(1952). Dalam tabel berikut adalah kumpulan cerpen Sunda karya satu orang pengarang

Tabel 1: Perkembangan Buku Kumpulan Cerpen Sunda

\begin{tabular}{|c|c|c|}
\hline Judul Buku & Pengarang & Tahun Terbit \\
\hline 1. Dogdog Pangréwong & G.S. & 1930 \\
\hline 2. Carita Biasa & R.A.F & 1959 \\
\hline 3. Papacangan & R. Sutiasumarga & 1960 \\
\hline 4. Hujan Munggaran & Ayatrohaédi & 1960 \\
\hline 5. 40 Dongéng Énténg ti Pasantrén & R.A.F & 1961 \\
\hline 6. Néangan & Caraka & 1962 \\
\hline 7. Jurig & Tini Kartini & 1963 \\
\hline 8. Béja ti Manéhna & Ki Umbara & 1964 \\
\hline 9. Parawan & Yus Rusamsi & 1964 \\
\hline 10. Di Luhureun Jukut Reumis & Yus Rusyana & 1965 \\
\hline 11. Tamiang Meulit ka Bitis & Ermas & 1965 \\
\hline 12. Teu Tulus Paéh Nundutan & Ki Umbara & 1965 \\
\hline 13. Paséa & Tini Kartini & 1965 \\
\hline 14. Diwadalkeun ka Siluman & Ki Umbara & 1965 \\
\hline 15. Heuay & Eddy D. Iskandar & 1980 \\
\hline 16. $\quad$ Nu Teu Kungsi Kalisankeun & Abdullah Mustapa & 1981 \\
\hline 17. Nu Tepung di Imah Dukun & I. Asikin & 1983 \\
\hline 18. Nyi Karsih & Tini Kartini & 1984 \\
\hline 19. Kanyaah Kolot & Karna Yudibrata & 1985 \\
\hline 20. Jajatén Ninggang Papastén & Yus Rusyana & 1988 \\
\hline 21. Halimun Peuting & Iskandarwassid & 1989 \\
\hline 22. Jiad Ajengan & Usép Romli & 1991 \\
\hline 23. Panggung Wayang & Aam Amilia & 1992 \\
\hline 24. $\quad$ Ceurik Santri & Usép Romli & 1985,1992 \\
\hline 25. Mirah Dalima & Kis W.S. & 1992 \\
\hline 26. Serat Sarwa Satwa & Godi Suwarna & 1995 \\
\hline 27. Oknum & Hadi A.K.S. & 1998 \\
\hline 28. $\quad$ Nu Harayang Dihargaan & D. Ariawinangun & 1998 \\
\hline 29. Pantun Pangrajah & Usman Supéndi & 2002 \\
\hline 30. Anak Jadah & Cécép Burdansyah & 2002 \\
\hline 31. $\quad$ Koruptor & O. Somara Dé Uci & 2002 \\
\hline 32. Anaking Jimat Awaking & Wahyu Wibisana & 2002 \\
\hline 33. Ajalna Sang Béntang Pilem & Duduh Durahman & 2004 \\
\hline 34. Rusiah Kaopatwelas & D. Ariawinangun & 2009 \\
\hline 35. Layung Katumbiri & Nunung Saadah & 2010 \\
\hline 36. $\quad$ Sapeuting di Cipawening & Usép Romli H.M. & 2010 \\
\hline 37. Halis Pasir & Us Tiarsa & 2010 \\
\hline
\end{tabular}

Sedangkan kumpulan cerpen yang berupa antologi bisa dilihat dalam tabel berikut ini. 
Tabel 2: Perkembangan Buku Antologi Kumpulan Carpon Sunda

\begin{tabular}{clc}
\hline No. & Judul Buku & Tahun Terbit \\
\hline 1. & Kandjut Kundang & 1963 \\
\hline 2. & Anting Pérak & 1966 \\
\hline 3. & Carécét Sulam & 1966 \\
\hline 4. & Demi Pasukan & 1966 \\
\hline 5. & Sawidak Carita Pondok & 1983 \\
\hline 6. & Petingan & 1983 \\
\hline 7. & Guriang Tujuh & 1984 \\
\hline 8. & Salumar Sastra & 1989 \\
\hline 9. & Ti Pulpén tepi ka Pajaratan Cinta & 2002 \\
\hline 10. & Kanagan 1 & 2003 \\
\hline 11. & Campaka Mangkak & 2003 \\
\hline 12. & Heulang nu Ngajak Béngbat & 2004 \\
\hline 13. & Surat keur ka Sawarga & 2004 \\
\hline 14. & Kembang Kadengda & 2007 \\
\hline 15. & Kanagan 2 & 2008 \\
\hline
\end{tabular}

Jika memperhatikan produktivitas lahirnya buku kumpulan cerpen Sunda dalam tabel di atas, terlihat ada masa yang kosong selama 29 tahun atau kumpulan cerpen tersebut tidak terbit dalam waktu lama. Pada dekade tahun 1940-an dan 1970an buku kumpulan cerpen itu tidak terbit. Ada kemungkinan pada tahun 1940-an, orang Sunda yang merupakan bagian dari bangsa Indonesia sedang menghadapi masa kesulitan karena perang, politik dan transisi kekuasaan. Sedangkan dekade 1970-an belum diketahui penyebabnya (Koswara, 2010:72).

Setiap kejadian dalam karya fiksi, sama halnya dengan kejadian dalam kehidupan sehari-hari. Dalam karya tersebut, setiap kejadian dilakukan oleh para pelaku tertentu. Dalam karya fiksi, sering dipakai istilah tokoh dan penokohan, watak dan perwatakan atau karakter dan karakterisasi yang sering kali diartikan sama. Padahal istilah-istilah tersebut sebenarnya mempunyai arti yang berbeda.

Menurut Nurgiyantoro (2009: 165), istilah tokoh, merujuk pada orangnya, pelaku cerita, misalnya sebagai jawaban dari pertanyaan; "Siapa tokoh utama dalam cerita itu?" atau "ada berapa orang jumlah pelaku cerita tersebut?".

Tokoh yang tampil dalam sebuah cerita, diberi watak sendiri-sendiri oleh pengarang. Adanya watak inilah yang menyebabkan adanya konflik, baik konflik antara tokoh dengan tokoh, tokoh dengan lingkungannya atau bahkan konflik dalam diri tokoh tersebut. Cara menampilkan tokoh yang seperti itulah yang disebut dengan penokohan.

Penokohan adalah bagaimana cara pengarang menggambarkan dan mengembangkan watak tokoh-tokohnya dalam satu cerita rekaan. Jones dalam Nurgiyantoro (2009:165), menyebutkan bahwa penokohan merupakan gambaran yang jelas tentang satu tokoh yang ditampilkan dalam sebuah cerita.

Menurut Pickering dan Hoeper dalam Minderop (2005:6), dalam menampilkan watak atau karakter tokoh, pengarang menggunakan cara atau metode dalam karyanya. Pertama menggunakan metode langsung (telling), kedua metode tidak langsung (showing).

Berkenaan dengan tehnik penokohan, Altenbernd dan Lewis dalam Nurgiyantoro (2009: 194-210), membagi tehnik penokohan 
menjadi 2, yaitu tehnik ekspositori dan tehnik dramatik. Dalam tehnik ekspositori, pelaku digambarkan langsung oleh pengarang. Sedangkan tehnik dramatik dibagi menjadi beberapa tehnik, diantaranya: 1) tehnik cakapan, adalah tehnik yang dipakai untuk menggambarkan watak pelaku dalam sebuah karya sastra; 2) tehnik tingkah laku, adalah tehnik yang terwujud dalam tindakan pelaku; 3) tehnik pikiran dan perasaan, watak tokoh akan tergambar dalam perasaannya dan juga jalan pikirannya; 4) tehnik arus kesadaran, adalah percakapan yang berlangsung dalam diri pelaku, atau sering disebut dengan monolog; 5) tehnik reaksi tokoh, adalah reaksi tokoh terhadap satu masalah atau satu kejadian dalam sebuah cerita; 6) tehnik reaksi tokoh lain, adalah pendapat pelaku lain terhadap pelaku utama atau sebaliknya; 7) tehnik pelukisan latar, adalah tehnik yang dipakai menggambarkan pelaku melalui latar belakang tempat dan latar belakang keadaan lingkungan sekelilingnya; 8) tehnik pelukisan fisik, adalah tehnik yang dipakai oleh pengarang dalam menggambarkan pelakunya lewat gambaran fisik pelaku.

Dari beberapa pendapat para ahli yang dijelaskan di atas, peneliti menyimpulkan bahwa dalam menggambarkan pelaku, khususnya pelaku utama dalam cerpen Sunda bisa dilakukan melalui tehnik sebagai berikut: 1) deskripsi pengarang tentang karakter tokoh; 2) percakapan tokoh; 3) tingkah laku tokoh; 4) gambaran fisik tokoh; 5) pendapat tokoh lain tentang tokoh utama atau sebaliknya.

Ibarat manusia dalam kehidupan seharihari, tokoh dalam karya sastra mempunyai tingkah laku dan watak sendiri-sendiri. Tingkah laku atau watak setiap orang dalam mereaksi setiap kejadian dalam kehidupan sehari-harinya sering disebut kepribadian. Sebab semua kebiasaan inilah yang akan digunakan oleh setiap orang dalam mereaksi setiap kejadian dalam lingkungan sekelilingnya. Robert Driscoll dalam Parengkuan (2010:7) menjelaskan bahwa kepribadian yang menjadi ciri khas setiap orang (life style), diformulasikan sejak orang itu belum mencapai usia 5 tahun. Artinya karakteristik seseorang yang awalnya terbentuk dalam pendidikan keluarga serta pengaruh lingkungan sekitarnya, akan menjadi karakter dasar seseorang, yang akan terbawa sampai seseorang itu dewasa. Seperti yang terlihat dalam bagan berikut ini.

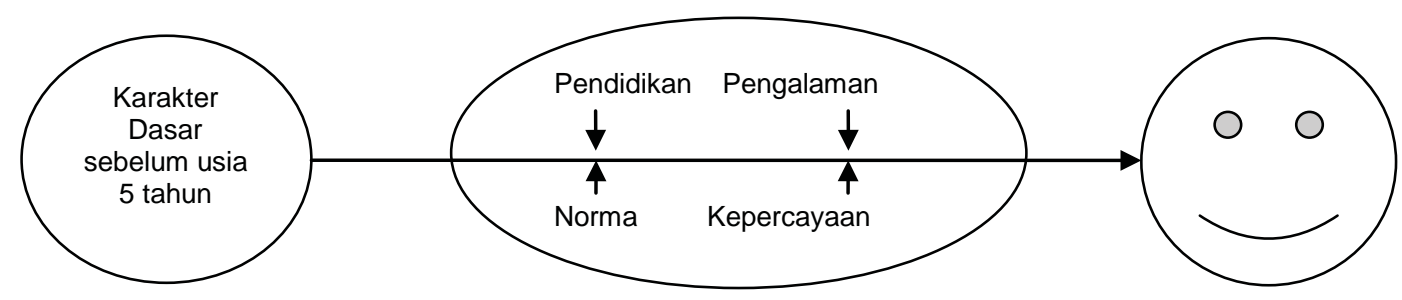

\section{Bagan 1: Kepribadian}

Menurut Hasan (2010:3), karakter, tokoh, akhlak atau kepribadian seseorang terbentuk dari hasil internalisasi bermacammacam kebaikan (virtues) yang diyakini serta digunakan sebagai dasar berpikir, bersikap, serta bertindak.
Kepribadian mencakup kebiasaan, sikap, dan sifat yang dimiliki seseorang yang berkembang jika seseorang itu mengadakan hubungan dengan orang lain diluar dirinya. Selain itu, kepribadian juga menghubungkan antara nilai-nilai, norma dan tingkah laku. Seperti yang terlihat dalam bagan dibawah ini. 


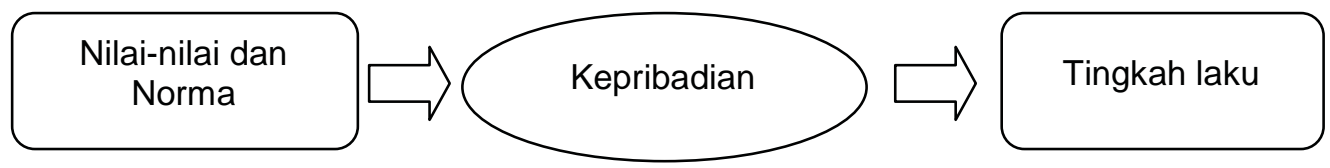

\section{Bagan 2: Hubungan antara Nilai-Nilai, Kepribadian, dan Tingkah Laku}

Tentang kepribadian, Koentjaraningrat (2002: 102), memberikan pendapatnya sebagai berikut, Kepribadian adalah ciri-ciri watak seseorang individu yang konsisten yang memberikan kepadanya sesuatu identitas sebagai individu yang khusus, yang maksudnya adalah orang tersebut mempunyai beberapa ciri watak yang diperlihatkan secara lahir, konsisten dan konsekwen dalam tingkah lakunya sehingga tampak bahwa individu tersebut memiliki identitas khusus yang berbéda dari individu-individu lainnya. Dalam memahami kepribadian manusia seutuhnya, tidak bisa lepas dari perkara ruh (inti) manusia yang memberikan dampak terhadap kepribadian itu sendiri. Sesuai dengan bentuk kejadiannya, manusia itu sudah dibekali dengan kebaikan, keburukan, petunjuk dan kesesatan, serta mampu membedakannya antara keempat bekal tersebut. Sesuai dengan firman Alloh dalam Al-Qur'an surat AsySyams ayat 7-10, yang artinya "...dan jiwa serta penyempurnaannya (ciptaannya), maka Alloh mengilhamkan kepada jiwa itu (jalan) kefasikan dan ketaqwaannya, sesungguhnya beruntunglah orang yang menyucikan jiwa itu, dan sesungguhnya merugilah orang yang mengotorinya".

Konsep kepribadian terus berkembang membentuk sebuah organisasi di-namis dalam diri individu yang merupakan respon terhadap sistem-sistem yang menentukan cara-cara menyelaraskan diri secara khas sesama individu terhadap lingkungannya (Najati, 2010:203). Sedangkan kepribadian menurut psikologi bisa diartikan selaku pola karakteristik tingkah laku dan pola pikir yang menentukan cara menilai seseorang terhadap lingkungannya.
Psikologi Kepribadian mempunyai fungsi deskriptif dan predikatif. Fungsi deskriftif merupakan fungsi untuk menjelaskan dan mengorganisasikan secara sistematis tingkah laku manusia atau kejadian-kejadian yang dialami sesama individu. Sedangkan fungsi predikatif merupakan fungsi untuk meramal tingkah laku, kejadian, atau akibat yang akan terjadi terhadap sesama individu.

Konsep psikologi kepribadian yang digunakan dalam penelitian ini adalah aliran psikoanalisis Carl Gustav Jung. Menurut Carl Gustav Jung, perhatian ma-nusia dalam kehidupannya tertuju pada dua arah. Ke luar dirinya, dan ke dalam dirinya. Atau sering disebut dengan manusia yang berkepribadian ekstrovert dan introvert. Menurut Suryabrata (2008:162), manusia yang berkepribadian ekstrovert biasanya mempunyai sifat-sifat yang lebih terbuka, lancar dalam bergaul dengan sesamanya atau lingkungannya. Sedangkan manusia yang mempunyai kepribadian introvert cenderung mempunyai sifat kurang bisa bergaul, pendiam, lebih senang sendiri (individualistis), sangat susah untuk ditebak hatinya.

Yang disebut orang Sunda dalam penelitian ini adalah sebagaimana yang dijelaskan oleh Suryalaga (2010:69-72), bahwa yang disebut orang Sunda itu berdasar pada 5 kategori: 1) Sunda Subjektif, adalah orang yang berdasarkan pertimbangan subjektifnya merasa orang Sunda, maka bisa disebut orang Sunda. oleh sebab itu dalam kehidupan sehari-harinya harus melaksanakan dan menggunakan normanorma atau nilai-nilai kesundaan; 2) Sunda Objektif, seandainya seseorang dianggap orang Sunda oleh orang lain, maka sudah 
selayaknya orang tersebut kudu "nyunda", atau mengaktualisasikan anggapan tersebut. Dengan cara melaksanakan dan menggunakan norma-norma atau nilai-nilai kesundaan; 3)Sunda Genetik, yaitu seseorang yang secara genetik lahir dari orang tuanya yang berketurunan Sunda asli; 4) Sunda Sosiokultural, jika seseorang mempunyai orang tua yang salah satunya orang Sunda asli dan tingkah lakunya "nyunda", maka dia layak diebut orang Sunda; 5) Sunda Geografis-Demografis, adalah setiap orang yang mendiami tatar Sunda secara geografis (secara administratip disebut provinsi Jawa Barat).

Menurut Rosidi (2009: 1-5) yang disebut manusia Sunda itu adalah manusia yang sehari-harinya memahami serta menjalankan nilai-nilai budaya Sunda.

Sebagai salah satu masyarakat budaya yang hidup diantara masyarakat dan budaya lain, sudah selayaknya orang Sunda mempunyai pandangan hidup yang berbeda dengan masyarakat lainnya. Menurut dalam menjalankan kehidupannya, etnis Sunda mendasari dirinya dengan citra insan yang akhlakul karimah, yaitu manusia yang senantiasa memegang teguh antara agama, sosial dan ekonomi.

Ciri lain yang dimiliki orang Sunda menurut Koentjaraningrat (2004:310) adalah sangat bangga terhadap budayanya serta pandangan-pandangan hidupnya yang mempunyai nilai tinggi. Menurut Suryalaga (2010:vii), dengan menjalankan pandangan hidupnya dalam tingkah laku sehari-hari, sifat dasar manusia Sunda menjelma dalam sifat cageur, bageur, pinter, singer, pangger dan cangker.

Sikap orang Sunda yang positif, tentu saja dibarengi juga dengan sikap yang negatif. Orang Sunda itu senang membodohi diri sendiri dengan menutup kenyataan oleh ucapan yang membuat enak di hati. Contohnya seperti: "Urang Sunda mah lemes budina, resep ngéléhan, sok ngaheulakeun batur", "urang Sunda mah tara karooh ku kalungguhan”, “urang Sunda mah jembar haté". Padahal dalam kenyataan sehari-hari, kita banyak menyaksikan banyak sekali orang Sunda yang mau dan akan melakukan apa saja agar keinginannya tercapai, termasuk untuk mendapatkan jabatan. Dari sikap seperti ini bisa disimpulkan bahwa orang seperti ini adalah munafik, ucapan tidak sama dengan tingkah lakunya. Sesuai dengan pendapat Hidajat dalam Rosidi (2009:51), bahwa sebelum mendirikan Pagoeyoeban Pasoendan (1913), Edi S. Ekadjati merumuskan, bahwa yang menyebabkan orang Sunda tertinggal oleh orang lain adalah "faktor mental dan pendidikan orang Sunda yang tidak memperlihatkan kreativitas, dinamika, keuletan, keberanian dan etos kerja yang tinggi". Apakah benar demikian? Belum ada penelitian secara ilmiah tentang hal itu. Jadi belum bisa dibantah, dan juga belum bisa diterima.

Dengan menggunakan tehnik sampling, peneliti menetapkan bahwa sumber data dalam penelitian ini adalah 35 cerpen Sunda. Dengan pertimbangan cerpen yang terpilih mempunyai ciri-ciri karya sastra yang baik. Karya sastra yang baik itu bisa mengungkapkan aspek kejiwaan yang baik, isinya merupakan suatu ikatan yang utuh antara bentuk, bahasa dan isi, serta adanya ajaran moral dan tingkah laku. Selain itu yang menjadi pertimbangan adalah selaku karya sastra yang menjadi cermin kehidupan (mimetik), cerpen Sunda yang terpilih bisa menghibur dan besar sekali manfaatnya untuk pembaca. Sesuai dengan konsep Horace berkenaan dengan dulce et etile, bahwa karya sastra itu mempunyai fungsi menghibur sekaligus mengajarkan satu hal. Hal ini bisa disimpulkan bahwa karya sastra yang baik itu selain indah, manfaatnya juga besar. Cerpen yang terpilih dalam penelitian ini adalah seperti terlihat dalam tabel berikut. 
Tabel 3: Cerpen Sunda yang Dianalisis

\begin{tabular}{|c|c|c|}
\hline Judul Cerpen & Pengarang & Tahun \\
\hline 1. "Pacul" & Caraka & 1953 \\
\hline 2. "Si Kabayan dina Poéan Lebaran" & Utuy T. Sontani & 1953 \\
\hline 3. "Nini" & J. Nirmala & 1955 \\
\hline 4. "Gotong Royong" & Caraka & 1963 \\
\hline 5. "Mojang dusun Meledug" & M. Rustandi K. & 1964 \\
\hline 6. "Tina Kahirupan Muhamad Insan" & Saini KM. & 1965 \\
\hline 7. "Ruhak Pajajaran" & Saleh Danasasmita & 1966 \\
\hline 8. "Pa Naib" & Karna Yudibrata & 1968 \\
\hline 9. "Dina Mumunggang Pasir" & Nana Darmana & 1969 \\
\hline 10. "Léngkah Lalaki" & Sunarya PK. & 1969 \\
\hline 11. "Raraméan" & Naneng Daningsih & 1970 \\
\hline 12. "Nu Butuh ku Pamuntangan" & I. Asikin & 1976 \\
\hline 13. "Masjid Jami" & Usep Romli & 1979 \\
\hline 14. "Hampura" & I Asikin & 1979 \\
\hline 15. "Panto" & Trisna Mansur & 1980 \\
\hline 16. "Mun Téa Manéhna Mulang" & Ahmad Aman & 1981 \\
\hline 17. "Piring Dinasti Ming" & Kis Ws. & 1982 \\
\hline 18. "Listrik" & T. Syarif Mahmud & 1982 \\
\hline 19. "Rojali Bin Haji Sanip" & Eson Sumardi & 1983 \\
\hline 20. "Bagus Jabin" & Yoseph Iskandar & 1989 \\
\hline 21. "Bilatung" & Cecep Burdansyah & 1990 \\
\hline 22. "Pajabat Manten" & Hidayat Soesanto & 1993 \\
\hline 23. "Potrét Tilu Jelema dina Albeum Kuring" & Cecep Burdansyah & 1993 \\
\hline 24. "Harga Kasatiaan" & Tetty Suharti & 1994 \\
\hline 25. "Simpé di Makam" & Yous Hamdan & 1995 \\
\hline 26. "Né Indung" & Sukaesih Sastrini & 1995 \\
\hline 27. "Nini" & Yus Fitradireja & 1995 \\
\hline 28. "Sintung Kalapa" & Iskandarwassid & 2000 \\
\hline 29. "Mulang" & Usep Romli HM. & 2002 \\
\hline 30. "Si Éta" & Ahmad Aman & 2003 \\
\hline 31. "Kanyaah Indung" & Tetty Hodijah & 2005 \\
\hline 32. "Bah Oyot" & Hidayat Soesanto & 2005 \\
\hline 33. "Nini Asmi" & Annisa Wulandari & 2006 \\
\hline 34. "Lokét Hideung" & Supriatna & 2006 \\
\hline 35. "Péngkolan Katilu" & Sin Soekarsono & 2007 \\
\hline
\end{tabular}

Setelah dianalisis berdasarkan gambaran 1) deskripsi pengarang, 2) omongan tokoh, 3) tingkah laku tokoh, 4) penampilan tokoh, dan 5) pandangan tokoh lain. Maka watak tokoh dalam cerpen terpilih akan muncul seperti dalam tabel berikut ini. 


\section{Tabel 4: Munculnya Kepribadian Pelaku Utama dalam Cerpen Sunda}

\begin{tabular}{|c|c|c|c|c|c|}
\hline \multirow[b]{2}{*}{ Judul Cerpen } & \multicolumn{5}{|c|}{ Munculnya Kepribadian Tokoh Utama } \\
\hline & $\begin{array}{l}\text { Deskripsi } \\
\text { Pengarang } \\
\text { (1) }\end{array}$ & $\begin{array}{c}\text { Omongan } \\
\text { Pelaku } \\
\text { (2) }\end{array}$ & $\begin{array}{c}\text { Tingkah } \\
\text { lakunya } \\
(3)\end{array}$ & $\begin{array}{l}\text { Penampil- } \\
\text { annya } \\
\text { (4) }\end{array}$ & $\begin{array}{c}\text { Pandangan } \\
\text { tokoh lain } \\
(5)\end{array}$ \\
\hline 1. "Pacul" & - & 7 & 2 & - & - \\
\hline 2. "Si Kabayan dina Poéan Lebaran" & 3 & 4 & 2 & - & 1 \\
\hline 3. "Nini" & - & 2 & - & - & 13 \\
\hline 4. "Gotong Royong" & 5 & 7 & - & 2 & 2 \\
\hline 5. "Mojang dusun Meledug" & - & 13 & 5 & - & 10 \\
\hline 6. "Tina Kahirupan M. Insan" & 1 & 12 & 5 & - & 2 \\
\hline 7. "Ruhak Pajajaran" & 14 & 14 & 8 & 3 & 6 \\
\hline 8. "Pa Naib" & 3 & 8 & 4 & - & 7 \\
\hline 9. "Dina Mumunggang Pasir" & 6 & 3 & 2 & - & 1 \\
\hline 10. "Léngkah Lalaki" & - & 9 & 3 & - & 13 \\
\hline 11. "Raraméan" & 7 & 3 & 1 & - & 5 \\
\hline 12. "Nu Butuh ku Pamuntangan" & - & 11 & - & - & - \\
\hline 13. "Masjid Jami" & 3 & 4 & 2 & - & 1 \\
\hline 14. "Hampura" & 1 & 4 & 5 & - & 9 \\
\hline 15. "Panto" & 8 & 7 & 7 & - & 8 \\
\hline 16. "Mun Téa Manéhna Mulang" & 5 & 17 & 2 & 1 & 18 \\
\hline 17. "Piring Dinasti Ming" & 1 & 15 & 2 & - & 5 \\
\hline 18. "Listrik" & - & 18 & 2 & - & 3 \\
\hline 19. "Rojali Bin Haji Sanip" & - & 23 & 2 & 1 & 20 \\
\hline 20. "Bagus Jabin" & 6 & 13 & 11 & - & 4 \\
\hline 21. "Bilatung" & 5 & 8 & 11 & - & 5 \\
\hline 22. "Pajabat Manten" & 22 & 12 & 2 & 1 & 3 \\
\hline $\begin{array}{l}\text { 23. "Potrét Tilu Jelema dina Albeum } \\
\text { Kuring" }\end{array}$ & 2 & 10 & 2 & - & 1 \\
\hline 24. "Harga Kasatiaan" & 1 & 7 & 2 & - & 1 \\
\hline 25. "Simpé di Makam" & 3 & 13 & 3 & 1 & 4 \\
\hline 26. "Né Indung" & 5 & 9 & - & - & 4 \\
\hline 27. "Nini" & 2 & 14 & - & - & 12 \\
\hline 28. "Sintung Kalapa" & 10 & 22 & 17 & - & 19 \\
\hline 29. "Mulang" & 9 & 6 & 1 & - & 8 \\
\hline 30. "Si Éta" & 14 & 5 & 6 & - & 11 \\
\hline 31. "Kanyaah Indung" & - & 6 & - & - & 2 \\
\hline 32. "Bah Oyot" & 9 & 6 & 1 & - & 3 \\
\hline 33. "Nini Asmi" & 9 & 12 & 3 & - & 1 \\
\hline 34. "Lokét Hideung" & - & 5 & 8 & - & - \\
\hline 35. "Di Péngkolan Katilu" & - & 15 & 4 & - & 10 \\
\hline
\end{tabular}

Berikut adalah beberapa contoh analisis cerpen berdasarkan unsur intrinsik dan teori psikologi Karl Gustav Jung.

\section{Cerpen Si Kabayan dina Poéan Lebaran}

Si Kabayan merupakan tokoh imajinatif masyarakat Sunda. Tokoh Si Kabayan juga sudah menjadi simbol jati diri manusia Sunda secara budaya. Tokoh Si kabayan akan menjadi sosok manusia Sunda yang berbeda, apabila diceritakan oleh orang yang berbeda.

Sosoknya seakan tak pernah mati, karena ia mampu berganti peran secara 
ekstensial. Ia pun bisa menyesuaikan diri sesuai perkembangan jaman yang semakin kompleks.

Tokoh utama dalam cerpen Si Kabayan dina Poéan Lebaran, adalah Si Kabayan yang hidupnya di jaman sekarang. Si Kabayan digambarkan oleh pengarang sebagai manusia yang jalan pikirannya agak beda dengan cara berpikir kebanyakan orang berpikir. Tingkah lakunya membuat orang tertawa tapi sekaligus membuat orang berpikir. Dalam cerpen ini, tergambar jati diri manusia Sunda pada jaman sekarang yang tidak merasa repot dengan adanya hari raya lebaran. Baginya, hari lebaran sama saja dengan hari-hari lainnya. Si Kabayan merasa bahwa yang namanya silaturahmi itu tidak harus pada hari raya saja, tapi harus dilaksanakan setiap saat dimana ada kesempatan. Ketika hari lebaran diajak ke kuburan untuk mendo'akan mertuanya, Si Kabayan pun menolak, karena mendo'akan orang tua itu termasuk mertua tidak harus pada hari lebaran saja. Tapi sebagai manusia yang beragama, hampir setiap waktu sholat kita berdo'a untuk kedua orang tua dan juga mertua. Tingkah laku Si Kabayan ini merupakan gambaran manusia Sunda jaman sekarang yang sudah serba praktis. Termasuk cara berpikirnya yang praktis. Karakter $\mathrm{Si}$ Kabayan ini digambarkan oleh pengarang melalui deskripsi pengarang, pembicaraan tokoh, tingkah lakunya serta reaksi tokoh lain terhadapnya.

Ditinjau dari segi psikologis, tokoh utama dalam cerpen ini secara hati termasuk ke dalam orang yang berkepribadian introvert, tapi secara pikiran bisa disebut extrovert. Karena, walau apapun yang dilakukannya harus selalu menguntungkan dirinya, tapi tetap jadi pemikiran kita. Dalam arti, pikirannya tertuju keluar dirinya. Menurut teori Carl Gustav Jung, kepribadian yang seperti ini sering juga disebut dengan kepribadian ambivert. Yaitu tipe campuran antara extrovert dan introvert.

\section{Cerpen Ruhak Pajajaran}

Tokoh utama dalam cerpen Ruhak Pajajaran adalan Nyi Puun Purnamasari (Putri Purnamasari). Dari deskripsi pengarang, omongan tokoh, tingkah laku dan penampilannya, serta reaksi tokoh lain terhadapnya, bisa disimpulkan bahwa Putri Purnamasari itu seorang pemimpin (puun) di sebuah dusun yang bernama Cidadap, mempunyai watak yang tegas, pemberani dan mempunyai rasa tanggung jawab yang besar terhadap masyarakat yang dipimpinya. Selain itu dia juga mempunyai watak penyayang. Watak inilah yang menyebabkan dia bisa memimpin rakyatnya dengan penuh kasih, sabar dan bijaksana. Nalurinya sebagai ibu begitu nyata terlihat ketika ia kehilangan anaknya. Hatinya begitu sakit dan pedih. Namun demikian dia tetap tegar dan tak pernah putus asa.

Sebagai manusia Sunda, Nyi Puun juga seorang wanita yang menjadi pemimpin mempunyai sifat bijaksana atau dalam bahasa Sunda leuleus jeujeur liat tali dalam mengelola rakyatnya. Dia juga tidak takut ketika harus harus menghadapi para perampok yang menjajah dan akan menguasai kapuunan nya. Baginya, Cidadap adalah generasi Pajajaran yang nantinya akan merebut kembali pusat kota dari tangan musuh. Dia juga mempunyai keyakinan bahwa Pajajaran akan berdiri kembali seiring berjalannya waktu dan akan berganti nama.

Ditinjau secara psikologi kepribadian aliran psikoanalisis Carl Gustav Jung, Nyi Puun mempunyai kepribadian yang extrovert, yaitu orang yang perhatiannya lebih tertuju ke luar dirinya, terbukti dengan tindakannya ketika menghadapi para perampok yang menyerang desanya. Dia lebih mementingkan keselamatan rakyatnya dibanding dengan keselamatan diri dan anaknya.

\section{Cerpen Pa Naib}

Dalam cerpen Pa Naib, sudah tentu yang menjadi tokoh utamanya adalah $\mathrm{Pa}$ 
Naib sendiri. Seorang penghulu yang selalu memberikan nasehat dan pencerahan pada umatnya. Namun mempunyai watak yang bertolak belakang antara omongan dan tingkah lakunya. Dari omongan dan rekasi pelaku lain, tergambar bahwa Pa Naib itu seseorang yang bisa disebut "ngelmu ajug", menerangi orang lain, tapi dirinya sendiri tetap dalam kegelapan. Satu sikap yang amat dilarang oleh orang Sunda.

Ditinjau dari psikologi kepribadian, sudah tentu orang seperti ini disebut introvert. Karena ia selalu memandang subjektif terhadap orang lain dan lingkungan diluar dirinya.

\section{Cerpen Hampura}

Tokoh utama cerpen Hampuran adalah Mang Alo. Mang Alo seorang tukang cukur yang mempunyai watak munafik, suka bersikap seenaknya sendiri terhadap orang lain, tak pernah menghargai perasaan orang lain, tak bisa dipercaya, bahkan hidupnya pun tak berpedoman pada agama. Walaupun pada akhir cerita ada keterangan yang menyebutkan dengan jelas mengapa Mang Alo mempunyai sikap seperti itu.

Jika melihat sifat Mang Alo yang jelek ini, tidak bisa dikatakan bahwa sifat inilah yang ada pada manusia Sunda. Karena sifat seperti ini hampir di setiap suku di Indonesia akan kita temui.

Sifat mang Alo yang seperti ini termasuk ke dalamorang yang berkepribadian introvert, karena semua sikap yang dilakukannya semata-mata hanya untuk keuntungan dirinya sendiri. Tanpa memikirkan orang lain dan lingkungan sekelilingnya.

\section{Cerpen Mulang}

Tokoh utama dalam cerpen Mulang bernama Mardi. Mardi adalah seorang bersuku Sunda asli, yang hidup dan mencari nafkah di daerah transmigran di sebuah daerah di Maluku, yang mempunyai watak ulet dan memegang teguh perintah agama. selain dari deskripsi pengarang, tuturan pelaku, tingkah laku dan reaksi tokoh lain, terlihat jelas dari sikapnya yang gigih mencari nafkah untuk keluarga sambil memegang teguh prinsip dan ketentuan agama.

Sikapnya yang penyayang, terhadap keluarga dan lingkungan sekitarnya, membuat Mardi disenangi dan dihormati oleh tetangganya yang tidak seagama, sehingga timbul sikap saling menghargai diantara mereka. Setiap sikap dan tingkah lakunya tidak pernah lepas dari aturan agama, karena Mardi pernah bersekolah di sebuah pesantren.

Sikap "nyunda" yang Islami dan Islam yang "nyunda", ia terapkan dalam mendidik anak dan istrinya. Hingga anak-anaknya merasa bangga menjadi orang Islam yang "nyunda" dan orang Sunda yang Islami, serta hidup diantara orang-orang yang bukan Islam dan bukan suku Sunda.

Kepribadian Mardi seperti itu, secara psikologi termasuk ke dalam orang yang berkepribadian extrovert. Yaitu orang yang perhatiannya tidak hanya pada diri dan keluarganya, tapi lebih kepada lingkungan hidup sekitarnya.

\section{Cerpen Nini Asmi}

Sesuai dengan judul cerpen, tokoh utamanya adalah Nini Asmi. Hal ini tergambar jelas dari keseluruhan isi cerita. Dari deskripsi pengarang dan respon tokoh lainnya, Nini Asmi adalah seorang perempuan tua yang berperawakan sehat dan kuat. Terlihat dari kegiatannya sehari-hari seperti ke kebun, ke pasar, memasak, bahkan mencari kayu bakar.

Nini Asmi seorang yang mempunyai sifat tegar, mandiri dan mempunyai sifat penyayang. Disebut tegar karena ia mempunyai sikap hati yang tetep kuat, tidak pernah takut menghadapi situasi dalam hidup yang tak pernah menguntungkan untuk dirinya. Sejak suaminya meninggal dunia, ia harus hidup sendiri, tanpa anak dan keluarga lainnya. Sedangkan sikap mandiri Nini Asmi, merupakan sikap bebas, dan 
hidup dengan tenaga sendiri tanpa bantuan orang lain.

Sikap Nini Asmi yang penyayang, merupakan sikap yang terwujud dalam sikapnya yang selalu ingin membuat orang senang, ingin memberi pada yang membutuhkan, dan sikap merasa kasihan terhadap orang lain dan juga pada binatang. Sikap penyayang Nini Asmi dalam cerpen ini terlihat dari tindakannya yang mengangkat seorang anak perempuan yang tidak normal. Sikap ini didasari oleh hatinya yang terusik melihat seorang anak perempuan di pasar yang sering diolok-olok orang gila.

Sikap seperti ini, oleh Carl Gustav Jung disebut extrovert, karena sikap Nini Asmi selalu tertuju pada orang lain dan lingkungan sekitarnya. Terutama yang membutuhkan bantuan. Walaupun sebenarnya dirinyapun sangat membutuhkan bantuan.

\section{SIMPULAN}

Sebagai salah satu suku yang hidup berdampingan dengan budaya lain, sudah selayaknya orang Sunda mempunyai pandangan hidup yang berbeda dengan masyarakat lainnya. Pandangan hidupnya itulah yang merupakan pola pikir yang utuh dan harus direfleksikan dalam kehidupan sehari-hari.

Orang Sunda yang sebagian besar menganut agama Islam, mempunyai implengan terhadap petunjuk-petunjuk agama. Walaupun pada kenyataannya tidak semua orang Sunda menjalankan kewajiban agamanya dengan sempurna.

Pandangan hidup yang didasari oleh agama Islam, dan mewarnai kehidupan orang Sunda, serta nilai-nilai budaya yang tercermin dalam kehidupan sehariharinya, sangat diperlukan untuk mengatur dan memberi petunjuk terhadap sikap dan tingkah lakunya dalam menjalani kehidupan.

Setelah memperhatikan hasil analisis dalam penelitian, bisa disimpulkan bahwa kepribadian manusia Sunda yang tergambar pada kumpulan cerpen tahun 1950-an sampai 2000-an mempunyai sifat yang dominan muncul adalah sifat sabar, tawakal, ramah, ikhlas, bijaksana, tanggung jawab, sopan, mengerti terhadap nilai-nilai atau norma yang ada di masyarakat, memegang teguh agama dan tradisi.

Dalam penelitian ini juga tergambar jelas bahwa kepribadian manusia Sunda dari masa ke masa mengalami perubahan, terutama perubahan ke arah kebaikan, yang menjadi pedoman hidup dalam menjalankan kehidupan sehari-hari.

Jika dilihat secara psikologis, kepribadian manusia Sunda yang tergambar dalam cerpen tahun 1950-an sampai dengan tahun 2000-an, $60 \%$ menunjukkan kepribadian yang extrovert, sedangkan yang $40 \%$ nya menunjukkan kepribadian yang introvert.

\section{PUSTAKA RUJUKAN}

Hasan, S.H., dkk. (2010). Pengembangan Pendidikan Budaya dan Karakter Bangsa. Bahan Pelatihan: Penguatan Metodologi Pembelajaran Berdasarkan Nilai-nilai Budaya untuk Membentuk Daya Saing dan Karakter Bangsa. Jakarta: Kementrian Pendidikan Nasional Badan Penelitian dan Pengembangan Pusat Kurikulum.

Koentjaraningrat. (2002). Pengantar Ilmu Antropogi. Jakarta : Rineka Cipta

Koentjaraningrat. (2004). Manusia dan Kebudayaan di Indonesia. Jakarta: Djambatan

Koswara, D. (2010). Sastra Sunda Modern. Bandung: JPBD FPBS UPI.

Minderop, A. (2005). Metode Karakterisasi Telaah Fiksi. Jakarta: Yayasan Pustaka Obor Indonesia.

Najati, M.U. (2010). Psikologi Qurani. Bandung: Marja.

Nurgiyantoro, B. (2009). Teori Pengkajian Fiksi. Yogyakarta: Gajah Mada University Press.

Parengkuan, E. (2010). Click! Strategi Taktis Berkomunikasi dengan Berbagai Kepribadian. Jakarta: PT. Gramedia. 
Rosidi, A. (2009). Manusia Sunda. Bandung: Kiblat.

Rusyana, Y, dkk. (1987). Pandangan Hidup Orang Sunda Seperti Tercermin dalam Tradisi Lisan dan Sastra Sunda. Penelitian Tahap I. Bandung: Bagian Proyek Penelitian dan Pengkajian Kebudayaan Sunda (Sundanologi) Direktorat jenderal Kebudayaan, Departemen Pendidikan dan Kebudayaan.
Suryabrata, S. (2010). Psikologi Kepribadian. Jakarta: Rajagrafindo Persada.

Suryalaga, H. (2010). Filsafat Sunda. Bandung: Yayasan Nur Hidayah.

\section{UCAPAN TERIMA KASIH}

Ucapan terima kasih saya sampaikan kepada Ketua Prodi SPs UPI beserta jajarannya. Tidak lupa pula kepada Penyunting Jurnal Lokabasa yang telah memuat tulisan saya ini, saya sampaikan penghargaan yang setinggi-tingginya. 